\title{
Challenges and Solutions for Biogas Production from Agriculture Waste in the Aral Sea Basin
}

\author{
Olimjon Saidmamatov ${ }^{1, * \mathbb{C}}$, Inna Rudenko ${ }^{1}$, Urs Baier ${ }^{2, *}$ and Elbek Khodjaniyazov ${ }^{1}$ \\ 1 Faculty of Tourism and Economics, Urgench State University, Urgench 220100, Uzbekistan; \\ irudenko@mail.ru (I.R.), khelbek@yahoo.com (E.K.) \\ 2 School of Life Sciences and Facility Management, Zurich University of Applied Sciences, \\ 8820 Waedenswil, Switzerland \\ * Correspondence: saidolimjon@gmail.com (O.S.); urs.baier@zhaw.ch (U.B.)
}

Citation: Saidmamatov, O.; Rudenko, I.; Baier, U.; Khodjaniyazov, E. Challenges and Solutions for Biogas Production from Agriculture Waste in the Aral Sea Basin. Processes 2021, 9 , 199. https://doi.org/10.3390/ pr9020199

Received: 18 December 2020

Accepted: 19 January 2021

Published: 21 January 2021

Publisher's Note: MDPI stays neutral with regard to jurisdictional claims in published maps and institutional affiliations.

Copyright: (c) 2021 by the authors. Licensee MDPI, Basel, Switzerland. This article is an open access article distributed under the terms and conditions of the Creative Commons Attribution (CC BY) license (https:// creativecommons.org/licenses/by/ $4.0 /)$.

\begin{abstract}
Energy plays an essential role in the modern society and can serve as one of the vital parameters of socio-economic development. Despite developments in technology, over three billion persons living in rural parts of the low- and middle-income countries continue to cover their energy needs for cooking through traditional ways by burning biomass resources. This paper as a case study focuses on the Aral Sea region of Uzbekistan, possessing a well-developed agricultural production with high livestock numbers and intensive crop production. The manure of the livestock farms is not used efficiently and the energy supply of the farms depends primarily on centrally produced gas and electricity. Some areas are not yet connected to the gas grid. Agriculture causes huge environmental damages in its current form. The benefit of biogas production would therefore be fivefold: (1) local energy source, (2) mitigation of environmental impacts, (3) reducing CH4-emissions, (4) producing organic fertilizer as a side product and (5) additional earnings for farmers.
\end{abstract}

Keywords: biogas; agriculture; Aral Sea; Uzbekistan; organic waste management; digestate

\section{Introduction}

There are enormous potential opportunities for biogas dissemination in developing countries, but inadequate infrastructure, insufficient capital and ineffective policy have hindered successful implementation [1]. Biogas technology in low- and middle-income countries can be considered as a clean energy innovation that still requires strategic advancement in all levels from small-scale (household or domestic implementation) to large-scale implementation for energy production and its transportation [1]. Considering that over $80 \%$ of the world's population live in developing countries, there are complex global challenges associated with organic agriculture, waste management, renewable energy and healthcare. Over $90 \%$ of the agriculture waste is often disposed of unregulated dumps or openly burned and sometimes treated by composting [2]. Indeed, biogas technology is a renewable and environmentally sustainable technology to cover waste and energy problems while growing agriculture productivity through treating biogas residue as organic fertilizers.

This paper focuses on the Aral Sea region of Uzbekistan, which is classified as a low-middle-income country [3]. Livestock breeding and farming are the most practiced activities among the rural population. Agriculture consumption is very high in the desert area and the land productivity is quite low [4]. Most of the residues from the agricultural sector are organic and can be considered feasible for anaerobic digestion. A biogas is generated first during the digestion process, leading to liquid digestate at the end of the process [5]. The livestock sector plays an important role and it is dominated by small household farms in rural communities. The land productivity is decreasing due to excessive surface irrigation using salinized water causing desertification [6]. The current agricultural practices are polluting the quality of soil while consuming high groundwater and energy. 
The livestock sector is dominated by small household farms and often provides the best livelihood option for rural families [7].

Local producers are permanently looking for new possibilities to improve their yield and the earnings and to reduce costs in order to survive in this competitive market field. In this context, the production of biogas could help reduce energy costs (mainly electricity) and increase crop yields due to the production of a high quality organic fertilizer [8]. Biogas production can also help reduce environmental risks, such as water evaporation caused by agriculture to improve the well-being of the families. As an environmental co-benefit, carbon emissions are being reduced. In the form of anaerobic digestion, waste can be transformed to bioenergy and digestate while minimizing greenhouse gas (GHG) emissions and potentially reducing the waste volume [9].

The Uzbek government is aware of the critical environmental situation in the Aral Sea basin which puts a high burden on agriculture, which represents the most common livelihood option in the rural population [10]. In addition, every seventh person does not have access to clean water globally [11]. This figure is extremely high in the Aral Sea zone, where almost all the population lacks access to pure drinking water, and irrigation water used for agricultural production is contaminated at higher than acceptable levels with different pesticides, herbicides and salts [12]. In line with decreasing the soil fertility rates and by that, affecting the income generation potential, lack of access to water for drinking, sanitation and hygiene escalates the worsening situation related to their well-being [13].

Creation of biogas plants improves the situation with cooking, water heating, bioenergy, digestate and further creates access to electricity, which improves the overall life standards of the rural population [14], especially housewives, who are totally responsible for taking care of the households.

\section{Literature Review}

\subsection{Biogas Practices in Low- and Middle-Income Countries}

Successful implementation of biogas projects in developed countries for agricultural waste-motivated biogas has occurred in a range of low- and middle-income countries, such as China, India, Nepal, Kenya [15]. Implementation of biogas has a different pattern in developing countries since they have various weather conditions, technologies, development levels, natural resources endowment and socio-economic conditions [16].

Most of the household biogas plants installed in China started providing energy for its rural areas and strengthening the biogas-based economy in 1974 [17]. The number of biogas plants was huge, but half of those plants failed in a short period of time due to poor design of digesters [18]. Agricultural-based projects gave a stimulus for improvement in biogas implementation in China, and biogas production is growing because of the industrial-scale digesters. Despite the impressive number of achievements, there are still several challenges regarding policy, poor industrial chain and technical problems caused by low-quality digesters [19].

In the case of India, government programs such as the National Biogas and Manure Management programme (NBMMP) served as a base in biogas implementation to enhance the energy service status of the people [20]. Most biogas plants consist of reactors that are intended to treat food wastes, cow dung, human excreta and mixed feedstock [21]. The process of wider implementation is still slow due to several factors, such as cost of installing a biogas plant, maintenance and reliability of the plant.

The biogas industry of Nepal has also advanced rapidly due to having geographic and socioeconomic similarities with India. In 1955, the first biogas plant was built to increase public awareness on this clean energy innovation in Nepal [22]. Stakeholder engagement of the biogas industry (i.e., Non-Governmental Organizations (NGOs), private sector) was a key reason for rapid advancement of the biogas sector [8]. Nepal finds it difficult to realize biogas projects in hilly areas due to cold temperatures there, and also some villages are not within reachable distance which makes installation of systems difficult. In addition, biogas technology is still not affordable for citizens in rural areas and there are no subsidies from 
authorities [23]. Poor water supply system in mountainous regions is not able to supply biogas plants with water [24].

Kenya is a comparatively developed country among African countries, however it faces some issues regarding energy, climate and food. In terms of the energy sector, Kenya heavily relies on traditional fuels such as biomass, charcoal and dung to satisfy heating and cooking needs due to the fact that Kenya produces no crude oil and there are no coal reserves. Firewood is considered the predominant fuel for cooking [25]. Biogas implementation in Kenya had its start in the 1950s as a pilot project. Various donation organizations and NGOs assisted to introduce biogas in technology in rural areas of Kenya, mostly relying on cattle manure as the main biogas substance [26]. However, these efforts did not provide the desired effect on implementing biogas technology on a wider scale due to several reasons, such as high construction and maintenance costs, absence of experience in constructing the plants and maintaining the digesters in operating conditions [27].

\subsection{Agriculture and Energy Conditions in Aral Sea Region of Uzbekistan}

Biogas production from agriculture waste has high ecological service value and economic impact, which could not only reduce the ecological environmental pollution, but also diminish the agricultural production demand for limited resources [18]. In the case of Uzbekistan, it has a comparative and competitive advantage on agriculture in comparison to its neighboring countries. Agriculture remained the most dominant sector in the economy until 2001 [28], while the livestock industry was a dominant contributor (40\%) to the Uzbek gross agricultural output [29]. The main characteristic of the sector is that most livestock production originates in small so-called dehkan farms. A huge number of family-owned farms (95-96\% with four heads of cattle on average) contrasts a small number of private livestock farms (4-5\% with 100-150 heads of cattle). Thus, the bulk of cattle in Uzbekistan is held by household farms: 4.5 million households keep more than 6 million cattle including 2.7 million cows-accounting for over $90 \%$ of Uzbekistan's herd [30].

In September 2020, the President of Uzbekistan, Mirziyoyev, delivered a speech at the UN General Assembly to direct global attention to solve ecological problems of the Aral Sea catastrophe. Releasing the consequences of desiccation of the Sea needs the active integration of international efforts [31]. As a result, the special UN Program was approved to provide effective assistance to the population affected by the Aral Sea.

Discussing the energy sector, a major share of electricity demand of the Aral Sea region is met by the Takhiatash thermoelectric power plant based on natural gas in the Republic of Karakalpakstan [32]. Local farmers cover their electricity needs from the central utility grid, however due to rationing and electricity shortages, they struggle to find alternative energy solutions [33]. Almost all farmers in the Aral Sea Basin are grid-connected since agricultural production is widely dependent on electricity consumption, with electric pumping-based surface irrigation being the most energy-intensive process. Electricity supply is highly unreliable and the grid often overloaded [28]. Like other emerging economies, grid connection to sell the generated green energy is at an early development stage. Legislation of the grid connection and feed-in tariffs are being evaluated by local authorities.

Farmers with off-grid diesel-based irrigation account for less than 2\%. Energy intensity in agricultural production is partly caused by the lack of knowledge and skills [34]. Electricity is the main power source for water pumps in the farms. In total, $80 \%$ of all arid lands are irrigated through water lifting techniques. Out of this share, more than half of the irrigation is done by using electric power. Gravity irrigation is used for around $20 \%$ of the arid lands, while around $20 \%$ of the water is pumped by using resources such as oil, natural gas and animal power [35]. 


\subsection{The Most Important Local Needs}

In spite of the continually rising energy demands, millions of communities, particularly in developing countries, still are in shortage of access to electricity and natural gas [36]. In the case of Uzbekistan, all energy problems and its solutions are associated with the agriculture industry [14]. Ten percent of the total land area in Uzbekistan is used for agricultural production purposes.

Livestock breeding (cattle), is a major economic activity in the Aral Sea Basin. Cattle breeding is also a regular household activity, making $60 \%$ of the households self-subsistent on meat and dairy products [37]. Moreover, it is an important source of income, since the Aral Sea region supplies a significant share of meat and dairy products for urban areas such as Uzbekistan's capital Tashkent.

Uzbekistan has a comparative and competitive advantage on agriculture and it was the most dominant sector in the economy until 2001. Rising market prices of provender significantly affect small Uzbek producers, because of their limited ability to pass on these price effects to the end consumer. Total profits in the Uzbek beef, lamb and pork industries are falling and competition is becoming stronger. As a result, large companies with a livestock of minimum 200-300 cattle are increasing their market share due to their ability to offer low prices as a consequence of economies of scale [23].

The local producers are permanently looking for new possibilities to improve the yield and the earnings and to reduce costs. Another important need is the reduction of land salinization, water evaporation and energy consumption caused by agriculture and diversifying and strengthening family income sources, especially for the women [38]. The biggest challenge in the Aral Sea basin is the high rate of water consumption of the agricultural areas. The reason is their location in desert zones. For the necessary irrigation, groundwater from very deep zones must be pumped. This situation creates high costs and intensifies the process of desertification [10].

\section{Field Evaluation}

To ensure affordable and clean energy (SDG 7) in the Aral Sea region of Uzbekistan, it is important to upgrade existing biomass resources (i.e., livestock manure, crop residues) to clean and green energy (i.e., biomass from anaerobic digestion) that can be a reason to mitigate negative consequences of climate change and environmental catastrophe in the Aral Sea basin of Central Asia.

With the support of the United Nations Development Programme (UNDP) project "Supporting Uzbekistan in Transition to a Low-Emission Development Path," the number of biogas plants increased to 42 units in 2015 [39]. According to preliminary calculations, this number of biogas plants is able to generate around 1,350,000 $\mathrm{m}^{3}$ of biogas per year, equivalent to approximately 2,700,000 kWh of electric energy. Given that the manure will be processed into bio-fertilizer, the annual GHG emission reductions could reach 7260 tons $\mathrm{CO}_{2}$-eq [39].

Economic development in the Aral Sea basin is lower compared to other parts of Uzbekistan. Thus, considering purchasing power of farmers, the majority of biogas plants are located in the eastern part of Uzbekistan (i.e., Tashkent, Fergana valley). Five biogas plants have been physically installed in the Aral Sea basin, although sustainable working procedures could not be assured until now because farmers and specialists did not have the professional capacity.

Field studies concerning biogas production from manure at livestock farms in the Aral Sea basin have been carried out recently by Urgench State University and the results are motivating. There is an interesting potential of agricultural biomass, and five farmers with a high number of animals have already announced high interest in producing biogas (Table 1, Figure 1). 
Table 1. Farmers with high interest in biogas production.

\begin{tabular}{|c|c|c|c|c|c|c|c|c|c|c|c|}
\hline \multirow{2}{*}{$\mathbf{N}$} & \multirow{2}{*}{$\begin{array}{l}\text { Name of } \\
\text { the Entity }\end{array}$} & \multicolumn{3}{|c|}{ Quantity (Head) } & \multicolumn{3}{|c|}{ Manure (ton/Day) } & \multirow{2}{*}{$\begin{array}{c}\text { Expected } \\
\text { Fermenter } \\
\text { Volume }\left(\mathrm{m}^{3}\right)\end{array}$} & \multirow{2}{*}{$\begin{array}{c}\text { Biogas Production } \\
\text { Potential } \\
\left(\times 1000 \mathrm{~m}^{3} / \text { Year }\right) \\
\end{array}$} & \multirow{2}{*}{$\begin{array}{l}\text { Total Di- } \\
\text { gestate } \\
\text { (tons/Year) }\end{array}$} & \multirow{2}{*}{$\begin{array}{l}\text { Greenhouse Gas } \\
\text { GHG Reduction } \\
\text { (tons } \mathrm{CO}_{2} \text { eq/Year) }\end{array}$} \\
\hline & & Cattle & Chick & Sheep & Cattle & Chicken & Sheep & & & & \\
\hline 1 & $\begin{array}{l}\text { "Agrofirma" } \\
\text { farmer } \\
\text { "Muslimova }\end{array}$ & 311 & & & 5 & & & 90 & 123.12 & 1524 & 284 \\
\hline 2 & $\begin{array}{l}\text { Sotima" } \\
\text { farmer } \\
\text { "Yuldosh }\end{array}$ & 74 & 100 & 25 & 1 & 0.02 & 0.015 & 22 & 23.62 & 287 & 51 \\
\hline 3 & $\begin{array}{l}\text { Majid" } \\
\text { farmer }\end{array}$ & 140 & & 133 & 2 & & 0.08 & 43 & 49.25 & 610 & 113 \\
\hline 4 & $\begin{array}{l}\text { "Biougit" } \\
\text { LLC }\end{array}$ & 200 & & & 3 & & & 60 & 73.87 & 914 & 170 \\
\hline 5 & $\begin{array}{l}\text { "Ibrohim } \\
\text { Bobo- } \\
\text { murod" } \\
\text { farmer }\end{array}$ & 96 & 200 & 50 & 1 & 0.03 & 0.03 & 30 & 27.66 & 312 & 59 \\
\hline
\end{tabular}

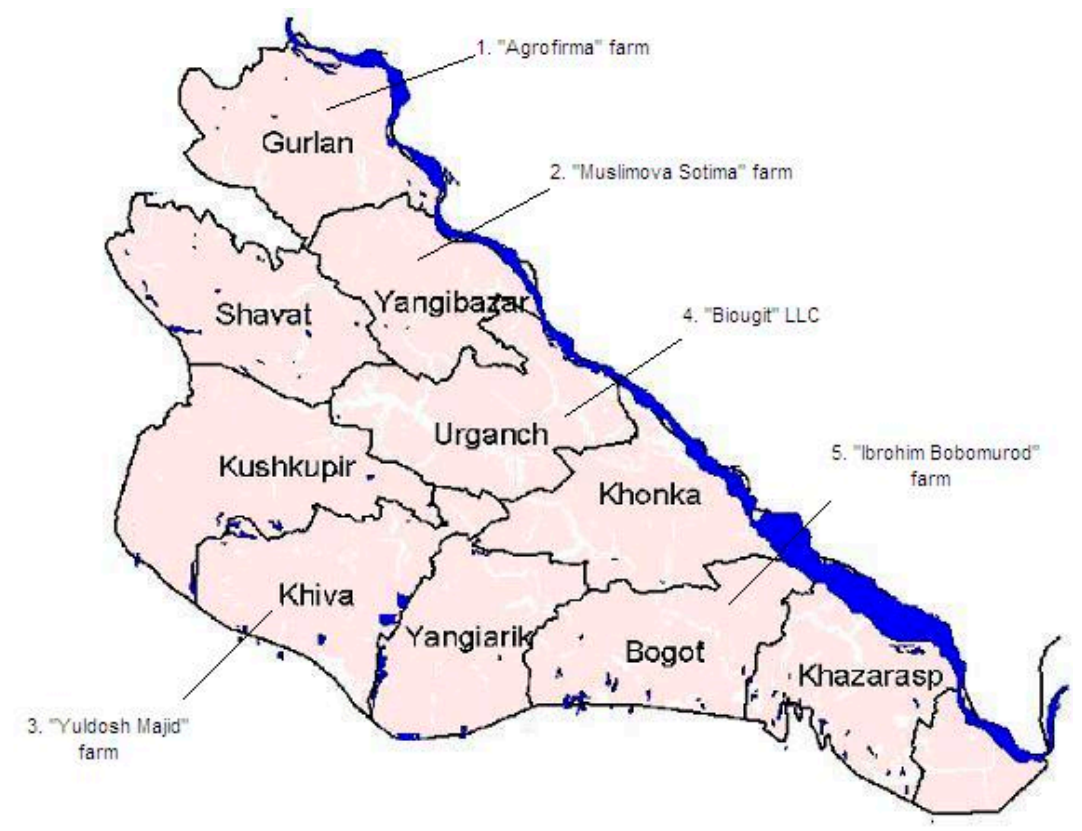

Figure 1. Map of Khorezm region and location of the five farms with high interest in biogas production.

Field trips and on-site evaluation and analysis were applied to access the current situation among existing biogas plants in the Aral Sea region. All these existing biogas plants faced technological failure due to not considering local ecological, environmental and agricultural factors before, during and after construction. In addition, only manure was considered as a main input material, however, other organic residues (i.e., cotton stalks, wheat straw, horticulture waste, vegetables) could enrich biogas generation. Biogas production potential of these five farms equaled to over $300,000 \mathrm{~m}^{3} /$ year with over 3600 tons digestate/year reducing 677 tons $\mathrm{CO}_{2}$ eq. /year greenhouse gas emissions annually.

There is an important potential from widely available biomass sources such as reed and sludges. It is important to study the potential of the various locally available sources for biogas production and to determine the implications using co-substrates on the technology as well as on the economy and on socio-environmental aspects. Special emphasis is directed to technologies digesting (semi-)solid biogenic wastes in order to reduce the use of water. 


\section{Field Trip Results}

Since Uzbekistan became an independent state in 1991, many outstanding reforms and government programs have been initiated to mitigate negative consequences related to natural resource depletion in the Aral Sea basin in the last three decades [10,11]. The Cabinet of Ministers approved the Decree \#343, "On Measures to Stimulate Construction of Biogas Plants" to support green energy generation. It is planned that dedicated bank loans with low interest rates will be provided to farming entities for the implementation of biogas plants [40]. Currently, commercial banks are introducing and testing loan conditions for farmers. The standardization Agency "Uzstandart" will be responsible for checking the appropriate working condition of biogas technologies. The local partners in this project will collaborate with the Agency. Surplus electricity generated from the biogas plant and not used by the local farms can be sold to "Uzbekenergo" Joint Stock Company (JSC), which is the operator of the centralized electricity grid [40].

- Most of the farms are located in remote areas with limited coverage of public utilities such as electricity grid, natural gas supply systems or tap water. Official statistics claim that 20 percent do not have access to the natural gas grid, and more than 10 percent are not connected to the electricity grid [41]. As most farmers are located in rural areas, it is hard for them to access sustainable electricity and natural gas from the central grid. Moreover, the central grid is unreliable, especially during the irrigation periods due to the overload demand.

- Most people in the remote areas are farmers and herders who need access to sustainable supply of electricity and natural gas for various purposes [32]. They need heat for cooking and space heating, which is crucial for their well-being, especially during the cold seasons. Importantly, the Aral Sea basin has extreme continental weather conditions which are dry hot in summer and dry cold in winter [10]. Farmers demand electricity for space lighting for use of basic electric equipment in remote places with no natural gas supply infrastructure. Electricity is also used for cooking and heating purposes. But, electricity is the main source of water pumps in the farms. In total, $80 \%$ of all arid lands are irrigated through water lifting techniques [10]. Out of this share, more than half of the irrigation is done using electric power [32]. Gravity irrigation is used for around $20 \%$ of the arid lands, while around $20 \%$ of the irrigation is done using resources such as oil, natural gas and animal power [41].

\subsection{Agrofirma, Khorezm Territorial Electricity Networks JSC, Gurlen District (with Biogas Plant)}

The farm of 130 ha owns 280 cattle of different sizes. It produces, among others, milk and yogurt. The manure on the cement ground of the stable is collected for anaerobic digestion. The cows are in summer for $4 \mathrm{~h}$ in the stable during the hottest period of the day and in winter longer when it is very cold. The biogas plant was installed by a third party in 2013 (Figure 2) with total capacity of 150 cubic meters (two tanks of $100 \mathrm{~m}^{3}$-see picture left—and $50 \mathrm{~m}^{3}$, respectively). The digesters are enclosed in a cottage and insulated with organic residues.

Currently, the system is not working. When the farm manager approached the company, it was not possible to identify problems. The digester is stirred by gas injection. In the digester there are an awful lot of pipes, which could be avoided to a large extent by a professional design. The input is very much diluted, which reduces its biogas potential. There are also a large number of fundamental technological challenges:

(a) Temperature within the tank is not kept stable (no thermometer inside the tank).

(b) If the information was correct, the digester is stirred by injection of air, which is poison for anaerobic digestion.

(c) The retention time-if amounts were correct-is only 15 days, what is at least half of the time recommended.

(d) Input and output pipes are next to each other, which causes an export of undigested manure (and an accordingly longer retention time of material in the back of the digester). 

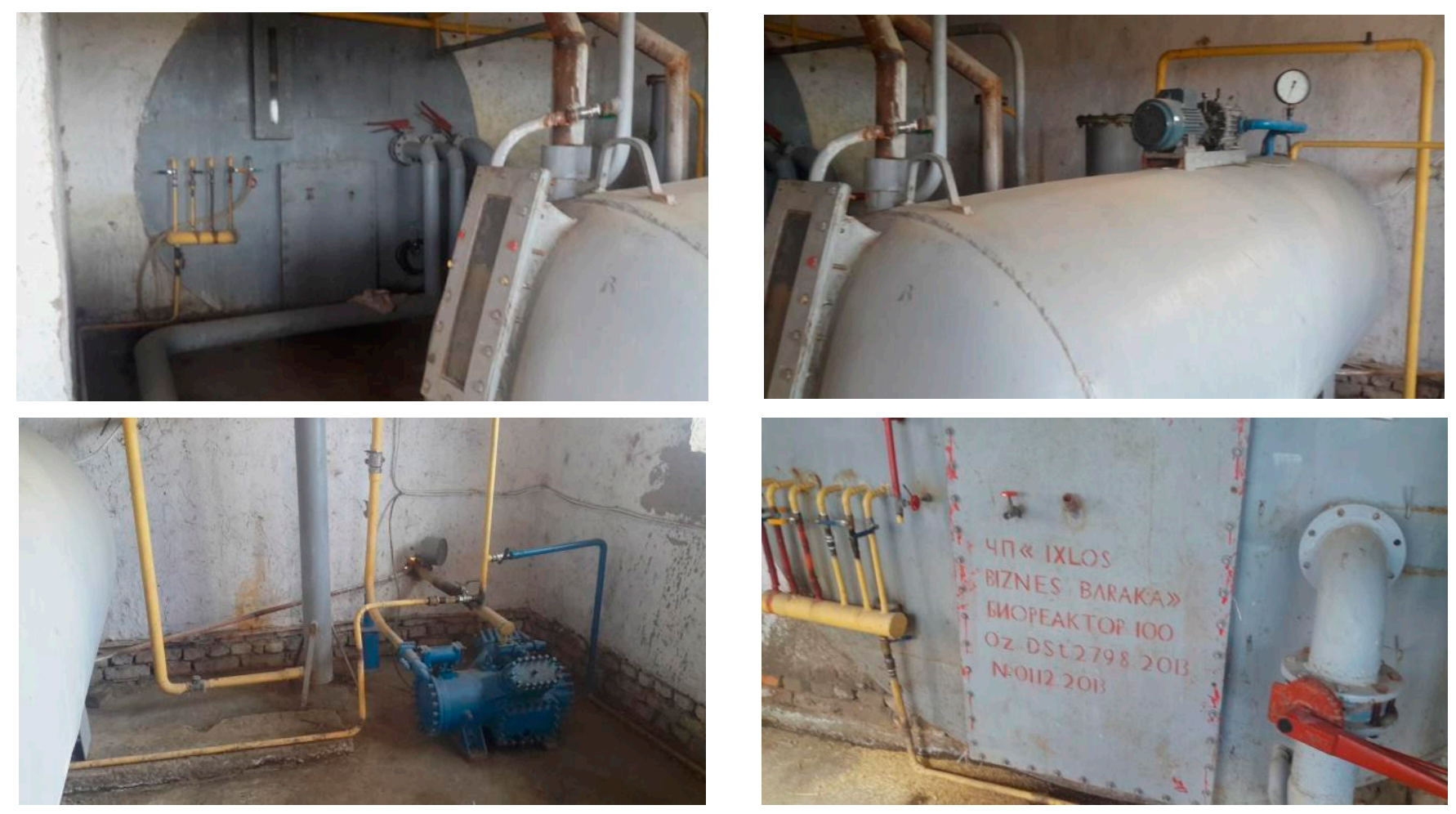

Figure 2. Biogas plant of the Agrofirma.

However, there is eventually the possibility to obtain additional wastes from neighbors, such as cotton residues. If a solution can be found to include the residues at the scratches outside, a solid waste digester could be the right solution.

\subsection{Muslima Sotimova, Yangibozor District (without Biogas Plant)}

Livestock farm "Muslima Sotimova" is located in Yangibozor district owning 20 hectares of agricultural land nearby (between others for corn production) to feed 80 cattle generating 300 tons of manure annually. The cattle remain on paved ground during the winter period. The owner of the farm has ambitious plans to construct a simple, low-cost biogas plant working without technical errors. Such a plant is expected to produce heat in the wintertime. If the farm decides to install a biogas plant, it can generate over $23,620 \mathrm{~m}^{3}$ biogas together with 287 tons of digestate annually.

\subsection{Yuldosh Majid, Khiva District (with Biogas Plant)}

The farm "Yuldosh Majid" with 140 cattle is located next to the border to Turkmenistan and to the desert. There is a biogas plant digesting a part of the manure (Figure 3). The plant consists of a $10 \mathrm{~m}^{3}$ digester (horizontal steel cylinder mounted on two supports) with a device for mixing the content of the digester manually (horizontal axis in the center). The gas is stored under pressure in a vertical cylinder. The liquid manure passes through a funnel to the inlet side and extracts the overflow to the opposite side, filling the small lagoon. There, the liquid-containing dissolved inorganic nutrients-seeps into the ground and into the groundwater, respectively. Remaining solids are collected and brought out to the field. 

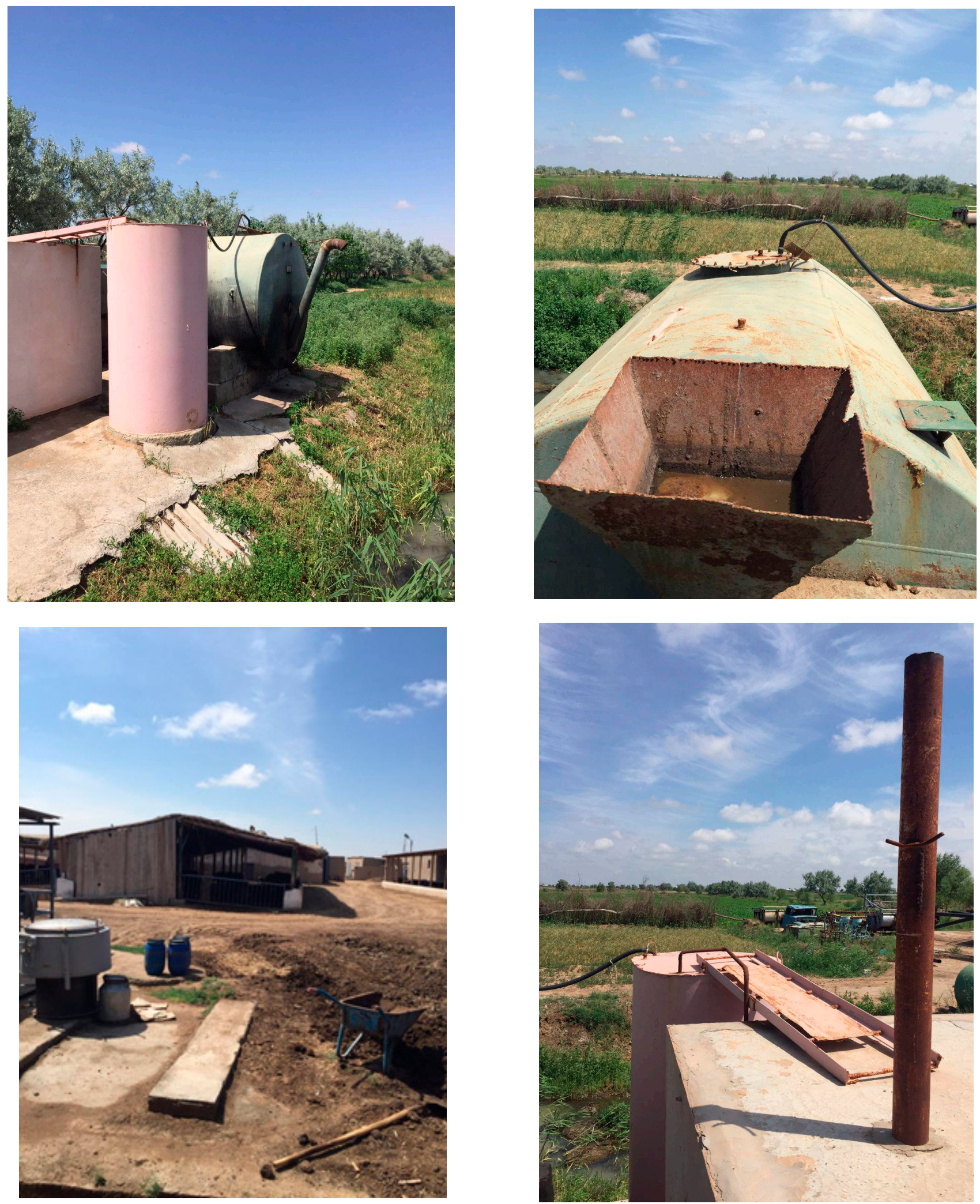

Figure 3. Biogas plant at Yuldosh Majid farm.

Unfortunately, there are additional unnecessary faults: i.e., the digester is not fed regularly, but only about once in a week. The digester is not insulated and is heated by an open fire under the tank. However, this concept is the best seen so far; it could be improved 
in several points and then be the simple solution for an application on small Uzbek farms with low-energy demand.

\subsection{Biougit, LLC, Urench District (with Biogas Plant)}

The farm has 200 cattle, and a biogas plant (Figure 4) —owned and operated by an external person-had been built. The biogas plant has a capacity of $60 \mathrm{~m}^{3}$, what is too low for 200 animals; the retention time was significantly less than 10 days. For this reason, the plant had to be regularly re-inoculated with material from a sewage treatment plant.
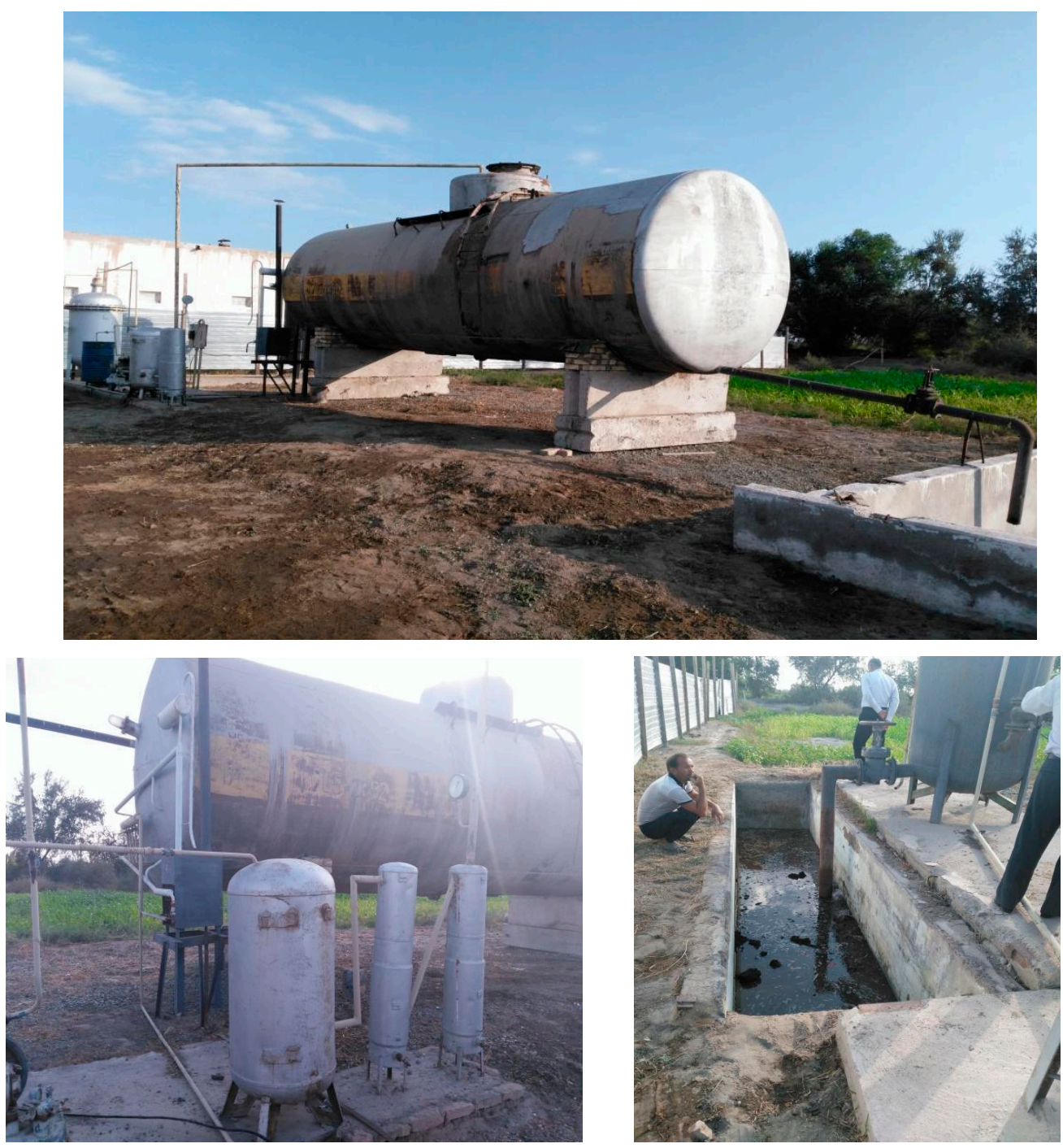

Figure 4. Biogas plant at Biougit Limited Liability Company (LLC).

Actually, the farm had been sold and there were no animals on the site. Thus, the operator had a deal with neighboring farmers who might sell manure to the Biougit LLC. The plant is not insulated and in wintertime the temperature may fall to nearly $-40{ }^{\circ} \mathrm{C}$. Because of the high ground water table, the digesters lay on supports above ground. The plant is stirred by gas injection. Because of lack of knowledge, there exists a variety of fundamental faults.

\subsection{Ibrohim Bobomurot, Bogot District (without Biogas Plant)}

"Ibrohim Bobomurot" farm, based in the Bogot district, has 100 cattle (50 milking cows and some young beefs) with arable land of 43 hectares, where 10 ha are cotton and 12 alfalfas. One ton of manure is collected daily and thrown sporadically into the water 
channels for fertilization and irrigation. Collected manure is distributed among farmer employees where they can use it for heating domestic ovens (i.e., to make bread and food and for heating in wintertime). The farm also intends to increase its chicken production.

The farmer shared that rice cover and cotton residue are available from his arable land. Like cotton residues, rice husks are not eaten by the cattle if they are produced in the "old way." If the organic wastes were laid down on the ground behind the cratches where the cows let fall a large part of their excrements, the mixture could be very good for biogas production, significantly increasing the biogas yield. Indeed, its biogas potential is over $27,660 \mathrm{~m}^{3}$ and can reduce 59 tons of $\mathrm{CO}_{2}$ emissions annually.

\section{Findings: from Challenges to Solutions}

With the announced support of the Government of Uzbekistan, biogas production can be developed towards economic viability. Production systems which will be economically viable can contribute a lot to improve the economic situation in the rural areas [14] via creating employment opportunities; providing access to sustainable energy [32]; and decreasing demand for natural resources [10]. Moreover, availability of biogas for cooking, water and space heating purposes directly improves the well-being of the women, creating comfortable cooking, hygiene and sanitation and living conditions. To reach economic viability the installations should be based on simple and proven technology. Introducing biogas technologies to farmers in Aral Sea basin and disseminating operating biogas plants in Khorezm region will bring the following socio-economic benefits:

a. Organic wastes will not be gathered in waste houses and methane emissions will be avoided.

b. The biogas plants will deliver the following products: biogas for heating the agrounit; digested manure withdrawn to feed the farmland towards increasing food production rate; delivery and sale of energy produced by biogas to the agro unit, other business units and households.

c. Increasing employment opportunities towards social and economic conditions of local people; increasing food supply in a sustainable, environmentally friendly way and decreasing the price of food.

d. The land supplied with digested manure will require less water. Water consumption in farmland will decrease the dependence to the most valuable natural resource.

Field trips to the biggest livestock farms in the Khorezm region revealed unique agriculture methods in each district. Treatment of organic wastes, energy management and cattle feeding techniques had a huge difference from each other with resilience to environmental conditions in the Aral Sea basin. A biogas on the farm is facing the following challenges: (1) the cattle are (at least in summer) outside in a coral on the unpaved, natural ground at the majority of the farms visited. Therefore, it is difficult to collect all the excrements widespread on the ground; (2) a large part of the excrements are dropped behind the cows when eating at the cratch, but this (wet) manure is mixed with earth and stones, i.e., it is not convenient to be used for digestion in a biogas plant that digests liquid input material. In the digester there will accumulate sediments of inert material, reducing very quickly the operating volume and necessitating costly and laborious revisions of the plant in short intervals; (3) digesting cattle manure has to be collected on a paved ground (at least behind the cratches) or the ground behind the scratches has to be excavated $\sim 40 \mathrm{~cm}$ and filled with harvesting wastes (cotton, rice, etc.). Then the upper layer with a mixture of manure and some harvesting waste-which has to be replaced afterwards—can be fed into the biogas plant. The mixture will result in a significantly higher biogas yield. This solution would also have a sanitary advantage: the cows will no longer stay in the mud, but on a more hygienic, drier surface.

Production of biogas, which allows the production of different types of energy and fertilizer, could be part of the solution. Introducing agricultural biogas production in the Aral Sea Basin can contribute to solve these needs: (1) Biogas plants will deliver locally produced electricity, heat and digested manure with nutrients in a plant available form; 
(2) the production of energy may help farmers to generate extra income by selling surplus energy to the grid or by using the generated energy on-site to reduce their energy costs; (3) at the same time, the biogas production can help to stabilize the electricity grid; (4) the high-quality organic fertilizer may reduce the input of expensive mineral fertilizer; (5) the spreading of the fertilizer from the biogas plant (digested manure) will reduce the evaporation rate; (6) the land productivity can be increased when digested manure is utilized in comparison with non-digested, ordinary manure; (7) hence, the treatment of organic waste in biogas plants helps to mitigate negative environmental effects in the Aral Sea basin, precisely in the Khorezm region. Considering local agriculture practices, ecological and environmental conditions, and biogas competence of local farmers, the following three model designs of biogas plants can be recommended to the local farmers and households as a solution to overcome the existing challenges in rural communities of Uzbekistan:

An Improved Design of the Simple Liquid Manure Digester of "Yuldosh Majid" Farm to Cover the Heat Demand of Small Farms Where the Cattle are Inside in Wintertime. The Solution (Figure 5) Needs Only Energy Efficient Materials to Cover the Digester which is Important to Control the Temperature Inside the Digester, Mostly in Winter.

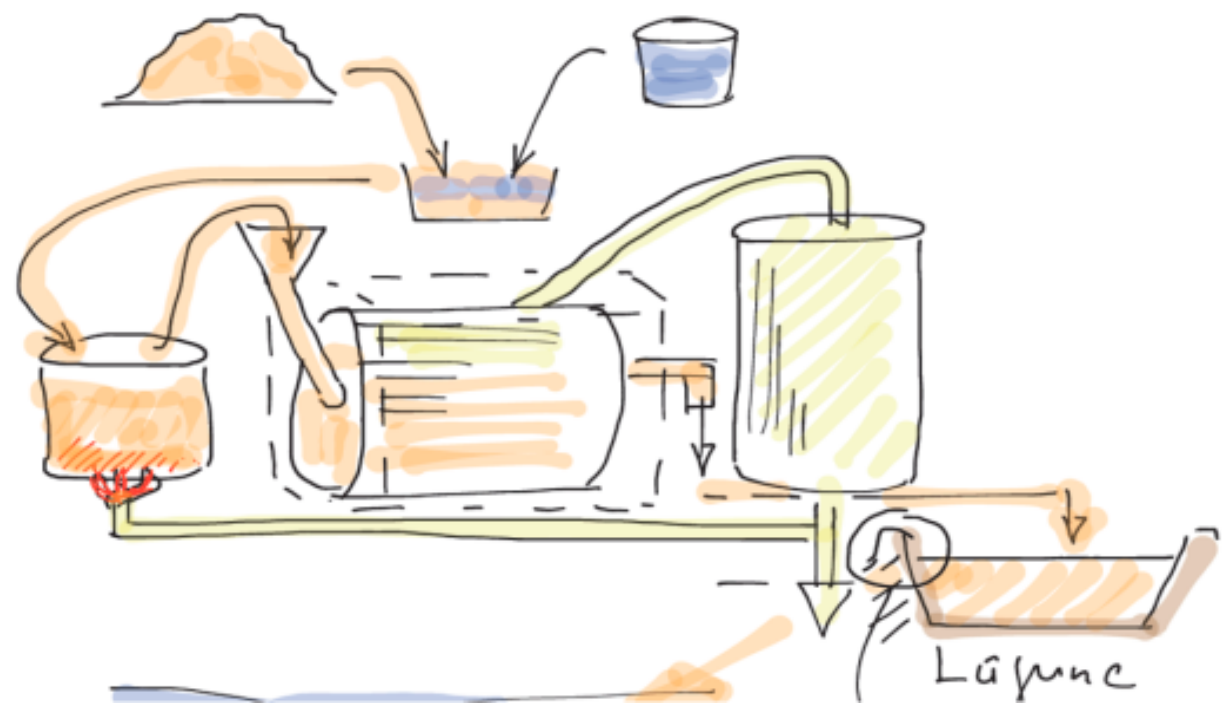

Figure 5. Improved design of the simple liquid manure digester [42].

Using the simple liquid manure digester, farmers can manually input the organic waste into the digester via inlet pipe, and a simple mixing device (driven by hand) accelerates the digestion process. Outlet pipes deliver the generated gas to the storage tank that is (mostly) used for cooking purposes. Finally, liquid digestate is collected at the end of the process and is used for agriculture purposes. Results of the field trip revealed that local farmers can buy this cylindrical metal silos at relatively low prices, but it had many deficiencies: it needs a lot of additional engineering and technical improvement, such as a simple heating device for warming up input (outside the digester) [42].

In general, simple liquid manure digesters can be improved as a low-cost solution due to its simple bio-technological processes. This option will be favored by local livestock farmers who extract the cattle manure manually to the outside of the farm. On its turn, recycled liquid manure can be treated as a digestate for the agriculture of the farm.

Simple Garage-Type Solid Waste Batch Digesters, Such as Those Developed by Renergon, Pöttinger and Other Companies are shown in Figure 6. 


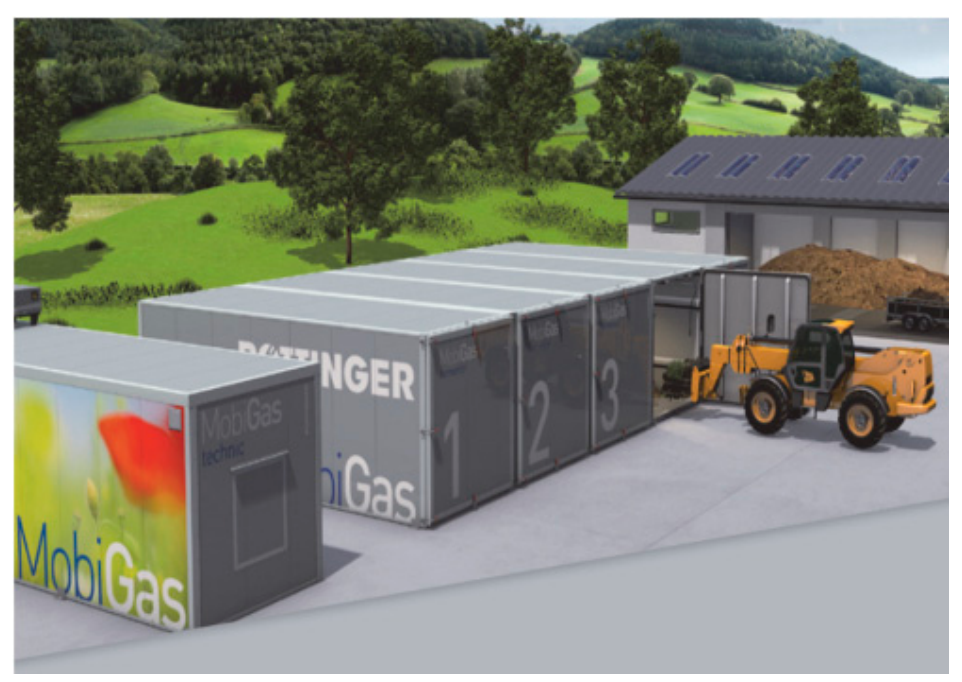

Figure 6. Simple garage type solid waste digesters [42].

Here, the solid manure is filled by turns with a truck into $3-5$ containers, where the material is digested over $4-5$ weeks. This solution shows several advantages: (1) There is no need for unnecessary dilution; water just requires volume, does not produce any gas and has to be heated to digestion temperature. Besides saving water and energy, there is a higher biogas output per digester volume; (2) it does not matter if the manure is spoiled by earth and stones because the input is loaded into and discharged from the container by truck (or by hand), i.e., the inert material remains in the digestate and can be brought out to the fields; (3) it is a modular design, i.e., if there is more input material in the future it is no problem to add an additional container.

This would be an optimal solution for the "Muslimova Sotima" and "Ibrohim Bobomurod" farms for covering their own high energy needs. In this case, these farms can feed the electricity into the grid at a reasonable price, but the owners are afraid of risking to invest on this type of biogas plant. Foremost, most of the farms are located within the same farming community which makes the manure transportation process more accessible.

A Modified Plug-Flow Digester for Semi-Liquid Digestion, Such as Those Developed by Arbi in Africa [43]. In Uzbekistan this Digester Has to be Heated, and at Large Volumes the Mixing Cannot be Done Manually, i.e., it Requires Some Additional Engineering and Cannot be Built Immediately (Figure 7).

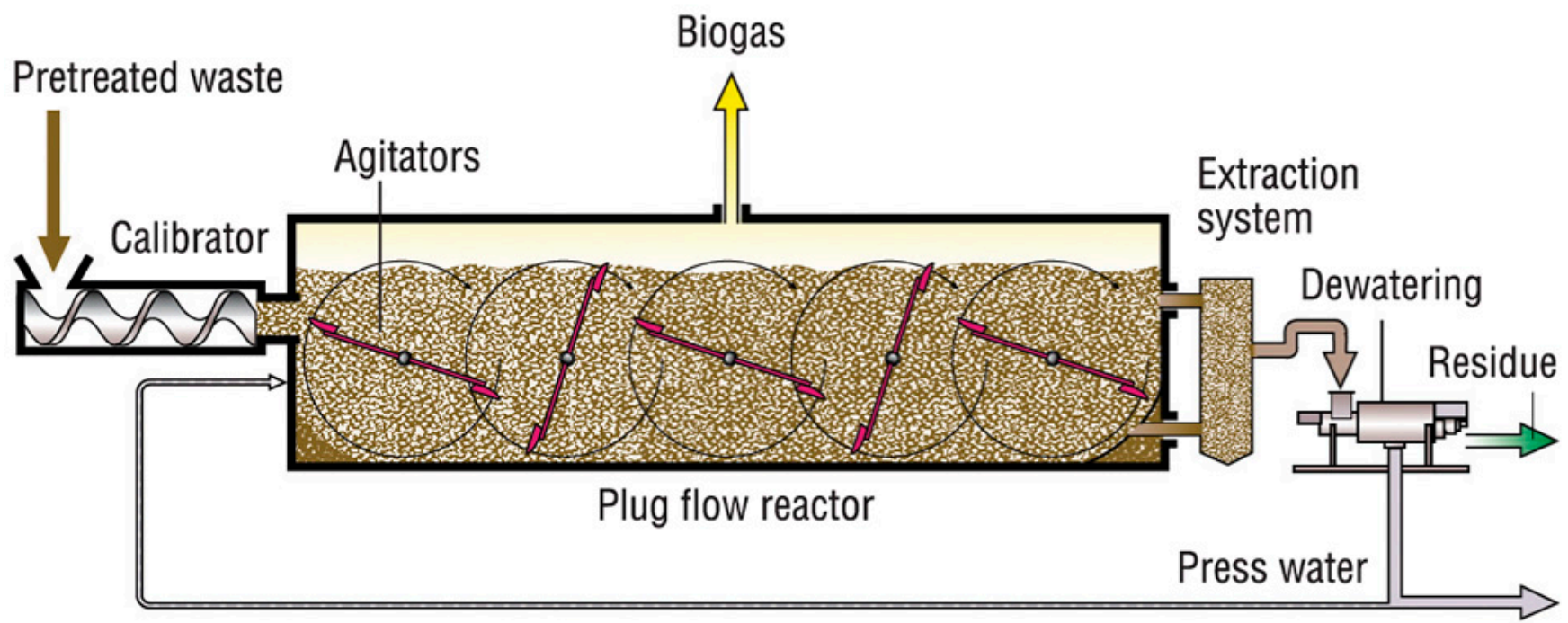

Figure 7. A modified plug-flow digester [42]. 
A plug-flow digester has long channels with an inelastic cover in which the manure rotates along a plug constantly through the digester. The system works well when the semi-liquid manure is inputted with over 13\% dry content. An example can be the manure from livestock farms with a retention time up to 20 days. This digester type is an optimal solution for farms that generate co-substrates (such as blood and rumen content from the slaughterhouse). It can be recommended to Yuldosh Majid and Agrofirma farms as (1) farmers have very low purchasing power and are afraid of investing in biogas projects; (2) $80 \%$ of the year consists of sunny days where a modified plug-flow digester for semi-liquid digestion operates efficiently. It is impossible to generate biogas in the winter period when the temperature is low ( $20 \%$ of the year).

The existing biogas plants focus only on animal manure, whose biogas potential is low due to its low caloric content (it has already passed through an intestine of an animal). It seems to be reasonable to add fresh biomass-so-called co-substrates, such as wastes from harvesting, rotten fruits, etc.-in order to increase the production significantly.

\section{Discussion and Conclusions}

With the absence of new policies to stimulate modern energy services, an additional 120-220 million people in low- and middle-income countries will still rely on traditional solid fuels and stoves by 2030, compared to in 2005 [44]. Eliminating the aforementioned challenges of biogas technologies in the Aral Sea basin serves as a potential strategy to support clean energy innovations Sustainable Development Goal 7(SDG7) in rural communities of Central Asia that mostly rely on agriculture.

In rural parts of Uzbekistan, peasant farmers are limited in their variety and quantity of products despite owning larger arable land. Hence, they cannot consider biomass plants as an active business earning. In addition to the economic benefits for the local beneficiaries [14], the introduction of biogas plants creates additional benefits for the region. The local producers and suppliers of components for the pilot plants will also benefit. On a general level, the biogas plants will reduce the negative ecological impact of agriculture in the Aral Sea basin [10] as well as reducing cost of doing business where access to sustainable energy is guaranteed [32].

Field visits to livestock farms led to the following, preliminary conclusions that can shape the further policies to develop biogas sector in Aral Sea basin of Central Asia:

1. The knowledge about biogas technology in Uzbekistan seems in the initial stage. The installations visited so far show severe technical deficiencies and there seems to be lacking know-how on plant operating. Capacity building in renewable energy will lead to the greening energy sector as well as mitigating negative consequences of climate change in the Aral Sea basin.

2. Like in most newly industrializing countries, in Uzbekistan biogas production concentrates on animal manure. However, excrements are not optimal for anaerobic digestion, because they have already passed through the intestine of an animal. Undigested organic matter, such as harvesting or organic household wastes, show a significant higher biogas potential than animal manure. However, the installations visited concentrate on animal manure alone without supplementing undigested so-called "co-substrates."

3. There are large farms with a high potential for producing biogas. They can produce a lot more energy than just covering their own needs. Unfortunately, these big farms are normally far from villages and houses, which could use the surplus heat for heating their buildings.

The most important local needs in rural areas of the Aral Sea basin are access to sustainable energy and improvement of family income, as well as environmentally friendly agricultural practices to reduce the water consumption and increase soil productivity [42]. Improvements in green energy innovations in ecologically vulnerable regions of low- and middle-income countries (i.e., Aral Sea basin) will enhance the economic condition of local 
families via creating access to affordable and clean energy (SDG 7) and organic agriculture, as well as employment opportunities.

Author Contributions: O.S. developed the first draft with the supervision of I.R., U.B. Contribution by authors: Conceptualization, O.S., E.K.; methodology, E.K.; software, I.R.; validation, U.B.; formal analysis, O.S.; investigation, E.K.; resources, O.S.; data curation, E.K.; writing—original draft preparation, O.S.; writing-review \& editing, U.B., E.K.; visualization, O.S.; supervision, U.B.; project administration, O.S.; funding acquisition, O.S. All authors have read and agreed to the published version of the manuscript.

Funding: This research paper generated scientific results of the development project "Biogas from Agricultural Waste in the Aral Sea Basin" funded by REPIC platform (Switzerland). Sincere gratitudes to Dr.Edelmann Werner, Mr. Hans Christian Angele, Dr. Bahtiyor Eshchanov and Ms. Manzura Iskandarova for their partnership in this development project funded by REPIC platform of Switzerland.

Institutional Review Board Statement: Not applicable.

Informed Consent Statement: Not applicable.

Data Availability Statement: Data is contained within the article and presented in the tables and figures.

Conflicts of Interest: The authors declare no conflict of interest.

\section{References}

1. Patinvoh, R.J.; Taherzadeh, M.J. Challenges of biogas implementation in developing countries. Curr. Opin. Environ. Sci. Health 2019, 12, 30-37. [CrossRef]

2. World Bank. Solid Waste Management: Understanding Poverty. 2019. Available online: https://www.worldbank.org/en/topic/ urbandevelopment/brief/solid-wastemanagement (accessed on 28 December 2020).

3. International Energy Agency, Energy and Climate Change. World Energy Outlook Special Report; IEA/OECD: Paris, France, 2015.

4. Aquastat. The Aral Sea Basin Transboundary River Basin. 2011. Available online: http://www.fao.org/nr/water/aquastat/ countries_regions/fussr/index5.stm (accessed on 1 January 2021).

5. Achinas, S.; Euverink, G.J.W. Theoretical analysis of biogas potential prediction from agricultural waste. Resour. Technol. 2016, 2, 143-147. [CrossRef]

6. Sokolov, V. Future of irrigation in Central Asia. In What Are the Prospects for the Future. In Proceedings of the IWMI-FAO Workshop on Trends and Transitions in Asian Irrigation, Bangkok, Thailand, 19-21 January 2009.

7. World Bank. Irrigation in Central Asia: Social, Economic and Environmental Considerations; World Bank: Washington, DC, USA, 2003.

8. Muradin, M.; Foltynowicz, Z. Potential for Producing Biogas from Agricultural Waste in Rural Plants in Poland. Sustainability 2014, 6, 5065-5074. [CrossRef]

9. United Nations Environment Programme. The Emissions Gap Report; A UNEP Synthesis Report; UNEP: Nairobi, Kenya, 2014.

10. Saidmamatov, O.; Rudenko, I.; Pfister, S.; Koziel, J.A. Water-Energy-Food Nexus Framework for Promoting Regional Integration in Central Asia. Water 2020, 12, 1896. [CrossRef]

11. UNDP. Human Development Report; United Nations: New York, NY, USA, 2019. [CrossRef]

12. Dukhovny, V.; Sokolov, V. Lessons on Cooperation Building to Manage Water Conflicts in the Aral Sea Basin; UNESCO-IHP: Paris, France, 2003.

13. Azouma, Y.O.; Jegla, Z.; Reppich, M.; Turek, V.; Weiss, M. Using agricultural waste for biogas production as a sustainable energy supply for developing countries. Chem. Eng. Trans. 2018, 70, 445-450. [CrossRef]

14. Saidmamatov, O.; Matyakubov, U.; Rudenko, I.; Filimonau, V.; Day, J.; Luthe, T. Employing Ecotourism Opportunities for Sustainability in the Aral Sea Region: Prospects and Challenges. Sustainability 2020, 12, 9249. [CrossRef]

15. Gao, M.; Wang, D.; Wang, Y.; Wang, X.; Feng, Y. Opportunities and Challenges for Biogas Development: A Review in 2013-2018. Curr. Pollut. Rep. 2019, 5, 25-35. [CrossRef]

16. Morgan, H.M.; Xie, W.; Liang, J.; Mao, H.; Lei, H.; Ruan, R.; Bu, Q. A techno-economic evaluation of anaerobic biogas producing systems in developing countries. Bioresour. Technol. 2018, 250, 910-921. [CrossRef]

17. Deng, L.; Liu, Y.; Zheng, D.; Wang, L.; Pu, X.; Song, L.; Wang, Z.; Lei, Y.; Chen, Z.; Long, Y. Application and development of biogas technology for the treatment of waste in China. Renew. Sustain. Energy Rev. 2017, 70, 845-851. [CrossRef]

18. He, K.; Zhang, J.; Zeng, Y.; Zhang, L. Households' willingness to accept compensation for agricultural waste recycling: Taking biogas production from livestock manure waste in Hubei, P. R. China as an example. J. Clean. Prod. 2016, 131, 410-420. [CrossRef]

19. Gao, M.; Wang, D.; Wang, H.; Wang, X.; Feng, Y. Biogas potential, utilization and countermeasures in agricultural provinces: A case study of biogas development in Henan Province, China. Renew. Sustain. Energy Rev. 2019, 99, 191-200. [CrossRef]

20. Mittal, S.; Ahlgren, E.O.; Shukla, P. Barriers to biogas dissemination in India: A review. Energy Policy 2018, 112, 361-370. [CrossRef]

21. Khan, E.U.; Martin, A.R. Review of biogas digester technology in rural Bangladesh. Renew. Sustain. Energy Rev. 2016, 62, 247-259. [CrossRef] 
22. Gautam, R.; Baral, S.; Herat, S. Biogas as a sustainable energy source in Nepal: Present status and future challenges. Renew. Sustain. Energy Rev. 2009, 13, 248-252. [CrossRef]

23. Karellas, S.; Boukis, I.; Kontopoulos, G. Development of an investment decision tool for biogas production from agricultural waste. Renew. Sustain. Energy Rev. 2010, 14, 1273-1282. [CrossRef]

24. Rupf, G.V.; Bahri, P.A.; De Boer, K.; McHenry, M.P. Barriers and opportunities of biogas dissemination in Sub-Saharan Africa and lessons learned from Rwanda, Tanzania, China, India, and Nepal. Renew. Sustain. Energy Rev. 2015, 52, 468-476. [CrossRef]

25. Sovacool, B.K.; Kryman, M.; Smith, T. Scaling and commercializing mobile biogas systems in Kenya: A qualitative pilot study. Renew. Energy 2015, 76, 115-125. [CrossRef]

26. Onthong, U.; Juntarachat, N. Evaluation of Biogas Production Potential from Raw and Processed Agricultural Wastes. Energy Procedia 2017, 138, 205-210. [CrossRef]

27. Hamid, R.; Blanchard, R. An assessment of biogas as a domestic energy source in rural Kenya: Developing a sustainable business model. Renew. Energy 2018, 121, 368-376. [CrossRef]

28. Libert, B.; Orolbaev, E.; Steklov, Y. Water and energy crisis in Central Asia. China Eurasia Forum 2008, 6, 9-20.

29. Rudenko, I.; Lamers, J. The Aral Sea: An Ecological Disaster. CUL Initiatives in Publishing (CIP). 2010. Available online: https: / / ecommons.cornell.edu/handle/1813/55717 (accessed on 2 December 2020).

30. ADB. Livestock Value Chain Development Project for Uzbekistan. 2016. Available online: https://www.adb.org/projects/52110001/main\#project-stories (accessed on 25 November 2020).

31. UzDaily. UN General Assembly Adopts a Special Resolution "Sustainable Tourism and Sustainable Development in Central Asia". 2019. Available online: https://uzdaily.uz/en/post/53803 (accessed on 1 January 2021).

32. Saidmamatov, O.; Salaev, S.; Eshchanov, B.R. Challenges and Optimization Strategy for Feed-In Tariffs of Renewable Energy in CIS Countries. Balt. J. Real Estate Econ. Constr. Manag. 2015, 3, 6-13. [CrossRef]

33. Granit, J.; Jägerskog, A.; Lindström, A.; Björklund, G.; Bullock, A.; Löfgren, R.; De Gooijer, G.; Pettigrew, S. Regional Options for Addressing the Water, Energy and Food Nexus in Central Asia and the Aral Sea Basin. Int. J. Water Resour. Dev. 2012, 28, 419-432. [CrossRef]

34. Piwowar, A.; Dzikuć, M.; Adamczyk, J. Agricultural biogas plants in Poland-Selected technological, market and environmental aspects. Renew. Sustain. Energy Rev. 2016, 58, 69-74. [CrossRef]

35. Micklin, P. The Aral Sea Disaster. Annu. Rev. Earth Planet. Sci. 2007, 35, 47-72. [CrossRef]

36. Surendra, K.; Takara, D.; Hashimoto, A.G.; Khanal, S.K. Biogas as a sustainable energy source for developing countries: Opportunities and challenges. Renew. Sustain. Energy Rev. 2014, 31, 846-859. [CrossRef]

37. Fumagalli, M. Food security in Central Asia: A priority for Western engagement. Cent. Asia Cauc. Anal. 2008, 10, 12-14.

38. Jalilov, S.M.; Amer, S.A.; Ward, F.A. Water, Food, and Energy Security: An Elusive Search for Balance in Central Asia. Water Resour. Manag. 2013, 27, 3959-3979. [CrossRef]

39. UNDP. Supporting Uzbekistan in Transition to a Low-Emission Development Path. 2016. Available online: https://www.uz. undp.org/content/uzbekistan/en/home.html (accessed on 1 January 2021).

40. Lex.uz. Decree of the President of Uzbekistan on Measures to Ensure the Rational Use of Energy Resources. 2017. Available online: https: / /www.lex.uz/docs/-3405580 (accessed on 26 November 2020).

41. Stat.uz. Annual Statistics of Agriculture, Energy, Water Sectors. 2018. Available online: https://stat.uz/uz/rasmiy-statistika/ release-calendar-2 (accessed on 1 January 2021).

42. REPIC. Biogas from Agricultural Waste in the Aral Sea Basin. 2019. Available online: http://www.repic.ch/repic-en/projects/ completed-projects/biomass/ebp-uzbekistan/ (accessed on 1 January 2021).

43. REPIC. The arbi Plug-Flow Digester in Tanzania: A medium-size Biogas Plant for Developing Countries. 2015. Available online: http:/ / www.repic.ch/files/6514/3645/5889/SB_Arbi_Tansania_vf_klein.pdf (accessed on 1 January 2021).

44. Pachauri, S.; Van Ruijven, B.; Nagai, Y.; Riahi, K.; Van Vuuren, D.P.; Brew-Hammond, A.; Nakicenovic, N. Pathways to achieve universal household access to modern energy by 2030. Environ. Res. Lett. 2013, 8, 024015. [CrossRef] 